\title{
A freaky motorbike accident causing vulvar hematoma: a case report at the Bafoussam Regional Hospital, West-Cameroon
}

\author{
Jovanny Tsuala Fouogue ${ }^{1 *}$, Gerard Tama Fetse ${ }^{2}$, Bruno Kenfack ${ }^{3}$, Jeanne Hortence Fouedjio ${ }^{4}$, \\ Florent Ymele Fouelifack ${ }^{5}$, Grace Kembaou Nganwa ${ }^{6}$, Michel Noubom ${ }^{7}$, Georges Enow Orock ${ }^{8}$, \\ Zacharie Sando ${ }^{9}$, Jean Dupont Ngowa Kemfang ${ }^{4}$
}

\begin{abstract}
${ }^{1}$ Department of Obstetrics and Gynecology, Bafoussam Regional Hospital, Cameroon
${ }^{2}$ Director of Bafoussam Regional Hospital, Cameroon

${ }^{3}$ Department of Obstetrics and Gynaecology and Maternal Health at the Faculty of Medicine and Pharmaceutical Sciences, University of Dschang, Dschang-Cameroon

${ }^{4}$ Department of Obstetrics and Gynaecology at the Faculty of Medicine and Biomedical Sciences, University of Yaounde 1. Yaounde, Cameroon

${ }^{5}$ Department of Obstetrics and Gynaecology, Yaounde Central Hospital, Yaounde, Cameroon

${ }^{6}$ Department of biological sciences at the Faculty of Medicine and Pharmaceutical Sciences, University of Douala, Douala-Cameroon

${ }^{7}$ Department of Microbiology, Immunology and Haematology at the Faculty of Medicine and Pharmaceutical Sciences, University of Dschang, Dschang-Cameroon

${ }^{8}$ Director of the Bafoussam Regional Hospital. Bafoussal - Cameroon

${ }^{9}$ Department of Morphological Sciences at the Faculty of Medicine and Biomedical Sciences of the University of Yaounde 1. Yaounde - Cameroon
\end{abstract}

Received: 16 June 2019

Accepted: 31 July 2019

\section{*Correspondence:}

Dr. Jovanny Tsuala Fouogue,

E-mail: fotsujo@outlook.com

Copyright: $($ ) the author(s), publisher and licensee Medip Academy. This is an open-access article distributed under the terms of the Creative Commons Attribution Non-Commercial License, which permits unrestricted noncommercial use, distribution, and reproduction in any medium, provided the original work is properly cited.

\begin{abstract}
Non-obstetric vulvar hematomas are rare and have never been reported in West Cameroon. No guidelines are available to inform the management of cases. Authors herein report the successful management of a post-traumatic vulvar hematoma in a 17 years old gravida 1 para 1001 patient. She was referred to our emergency department ten hours after a fall in a squatting position during a road traffic accident. Prior to the referral she had been managed conservatively by analgesics and a compressive dressing of the vulva in a community clinic. Clinical assessment on admission revealed a good general condition, normal vital signs and a tense and painful hematoma of the right labia. Surgery was done under general anesthesia to drain the hematoma, ligate the bleeding vessels and repair the vulva. Post-operative course was uneventful and the patient was discharge six days later. This case reminds practitioners in remote health facilities that early referral of this rare pathology contributes to its successful surgical management in our semi-urban region.
\end{abstract}

Keywords: Accident, Cameroon, Hematoma, Mortobike, Trauma, Vulva

\section{INTRODUCTION}

Vulvar hematomas are very rare and most of them are seen in obstetrics. ${ }^{1}$ Very few cases have been reported in Cameroon and none in the west region of the country (to 
the best of our knowledge). ${ }^{2-4}$ Non-obstetric vulvar hematomas (NVHs) are usually caused by direct trauma to the vulva during consensual or forceful sex/coitus and falls in squatting position. ${ }^{1,5}$ The loose connective tissue of the vulva is prone to accumulation of blood and expansion of the hematoma. ${ }^{5}$ There are neither guidelines nor consensus statements on best practices for the management of NVHs. ${ }^{5}$ We herein report a case of a large traumatic NVH successfully managed at the Bafoussam Regional Hospital (the referral Hospital for the west region of Cameroon).

\section{CASE REPORT}

Mrs. MM, 17 years old, G1P1001, married woman, with last menses 17 days prior to admission was referred to the emergency department of the Bafoussam Regional Hospital for better management of a vulvar trauma. She felt astride on the luggage carrier of the motorbike carrying her when it violently crossed a speed bump. She was immediately managed in a nearby community health facility where she received injectable analgesic and antiinflammatory drugs combined with a compressive dressing during about four hours. The persistence of the pain and the onset of a tense hematoma on the left vulva prompted her referral to the Bafoussam Regional Hospital.

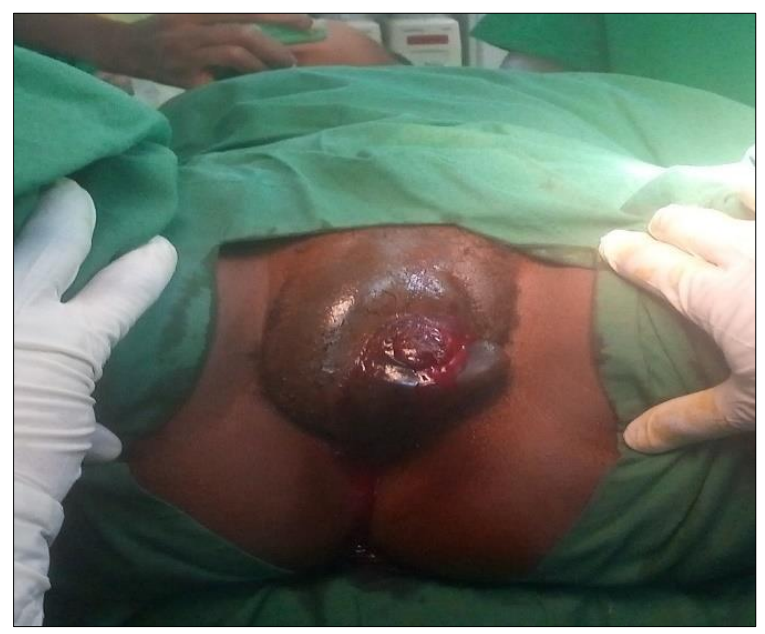

Figure 1: Post traumatic left vulvar hematoma (tense, painful and dehiscent).

Her past surgical, gynaeco-obstetric and medical history was unremarkable. On admission, she was hemodynamically stable and afebrile. Pre-operative workup was unremarkable except for a mild anemia (Hemoglobin level: 9.4 grams/deciliter). Giving the obvious evolution of the hematoma, imaging exploration was not requested. Management was based on surgical evacuation, hemostasis control and primary closure under general anesthesia. Exploration revealed a superficial hematoma lying mainly in the sub-cutaneous fat of the left labia and the lower fourth of the mons pubis (Figure $1)$.

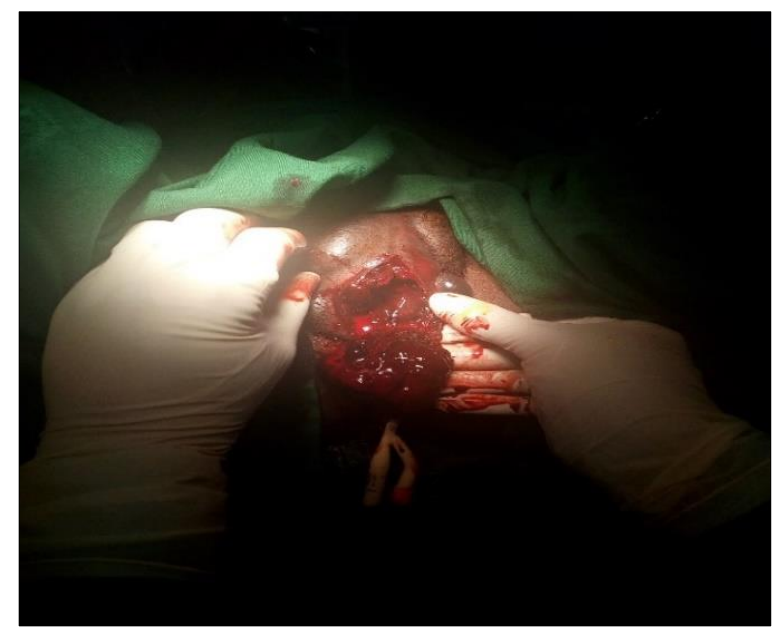

Figure 2: Evacuation of the hematoma unveiling bleeding vessels inside the bulbospongiosus muscle.

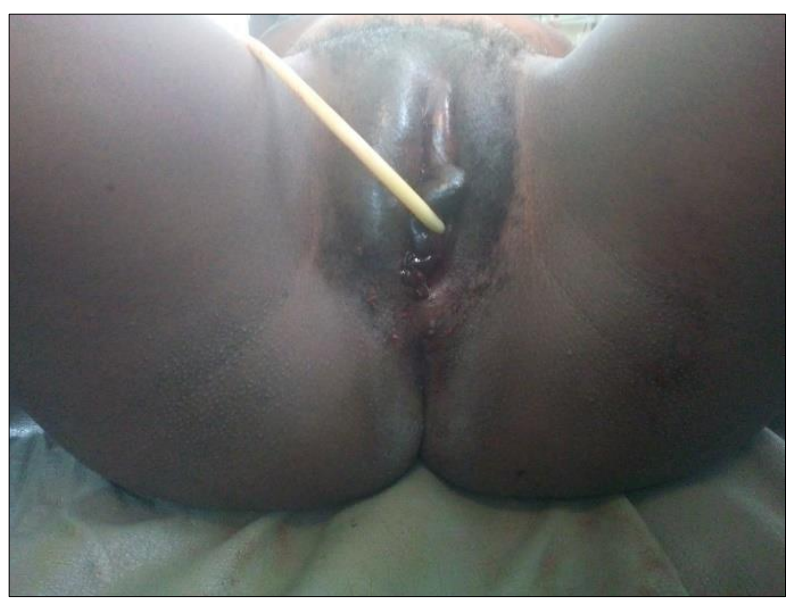

Figure 3: Aspect of the vulva after evacuation of the hematoma, hemostasis and closure.

Medially the hematoma was limited by the hymeneal caruncles and there was a small dehiscence in the interlabial cleft (Figure 2). Bleeding was from vessels of the superficial layers of the left bulbospongiosus muscle (Figure 3). After drainage and meticulous hemostasis control (suture ligation of all bleeding vessels), we did a layered closure of the cavity. The final aspect of the vulva was satisfactory (Figure 3 ) and transfusion of blood products was not required. Post-operative course was uneventful and the patient was discharged 6 days later (under sitz bath, hematinics and analgesics). She resumed sexual activity six weeks later without dyspareunia.

\section{DISCUSSION}

This case of NVH was the second managed in one year in our institution that serves as the referral Hospital for more than 2,000,000 people. This highlights the rarity of $\mathrm{NVH}$ in our setting. ${ }^{3}$ Clinical picture was classical: painful, tense and bulging hematoma of the vulva with dehiscence; signs of hypovolemic shock were absent. ${ }^{1}$ 
The causal mechanism in our case was similar to those commonly reported: soft tissues were crushed on the bony pelvis. ${ }^{1,5}$ The fall (in squatting position) on the luggage carrier could have been less severe if the motorbike had crossed the speed bump slowly. Excessive speed is a commonly reported cause of road traffic accidents in Cameroon. ${ }^{6}$

Early care seeking attitude of our patient led to early diagnosis which in turn allowed a trial of conservative management. This is not the case in NVHs due to coital trauma (especially in adolescents) because patients out of shame tend to hide the mishap. ${ }^{3}$ Despite the absence of guidelines, conservative management of (small) NVHs is very frequent; it is usually based on analgesics (systemic or local) and close monitoring. ${ }^{5}$ In our case antibiotics were added because of the dehiscence of the hematoma.

Imaging modalities are very useful to assess the extension of large vulvar hematoma. ${ }^{5}$ In our case it was not necessary. We were successful in achieving hemostasis by ligating all bleeding vessels in the bulbospongiosus muscle. When hemostasis is not surgically possible, arterial embolization is recommended. ${ }^{1}$ Unfortunately, this technique is currently not readily available in rich settings and absent in low-income countries like ours. Early referral for surgical exploration contributed to the overall good outcome of our case; this corroborates findings by Kanai et al. ${ }^{7}$

\section{CONCLUSION}

Though rare in our settings, NVH can be successfully managed if seen early at the appropriate level of care. Surgical procedure is simple and feasible in our context. Practitioners in rural underequipped settings are therefore encouraged to refer such cases.

\section{ACKNOWLEDGMENTS}

Authors are grateful to the staff of the maternity and surgical units of the Bafoussam Regional Hospital.
Funding: Funding sources from Bafoussam Regional Hospital

Conflict of interest: None declared

Ethical approval: Not required

\section{REFERENCES}

1. Ernest A, Knapp G. Severe traumatic vulva hematoma in teenage girl. Clinical Case Reports. 2015;3(12):975-8.

2. Fouelifack YF, Fouogue TJ, Fouedjio JH, Sando Z, Mbu RE. Massive postpartum vulvar hematoma: about one case at the Yaounde Central Hospital (Cameroon). Pan African Med J. 2014;19:167.

3. Tjek P, Essiben F, Moluh I, Tebeu PM, Fomulu JN. Hématome vulvaire massif post coïtal chez une adolescente. Health Sci Dis. 2013;14(4):3.

4. Tchounzou R, Chichom-Mefire A. Retrospective analysis of clinical features, treatment and outcome of coital injuries of the female genital tract consecutive to consensual sexual intercourse in the Limbe Regional Hospital. Sex Med. 2015;3:256-60.

5. Papoutsis D, Haefner HK. Large vulvar haematoma of traumatic origin. $\mathrm{J}$ Clin Diag Res. 2017;11(9):QJ01-QJ02.

6. McGreevy J, Stevens KA, Ekeke Monono M, Etoundi Mballa GA, Kouo Ngamby M, Hyder AA, et al. Road Traffic Injuries in Yaounde, Cameroon: hospital-based surveillance study. Injury. 2014;45(11):1687-92.

7. Kanai M, Osada R, Maruyama KI. Warning from Nagano: increase of vulvar hematoma and/or lacerated injury caused by snowboarding. J Trauma. 2001;50:328.

Cite this article as: Fouogue JT, Fetse GT, Kenfack B, Fouedjio JH, Fouelifack FY, Nganwa GK, et al. A freaky motorbike accident causing vulvar hematoma: a case report at the Bafoussam Regional Hospital, West-Cameroon. Int J Reprod Contracept Obstet Gynecol 2020;9:1321-3. 